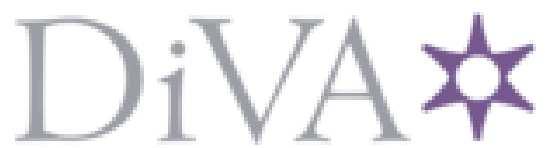

http://www.diva-portal.org

This is the published version of a chapter published in Addressing the Climate in Modern Age's Construction History: Between Architecture and Building Services Engineering.

Citation for the original published chapter:

Legnér, M. (2019)

Not Just a Summer Temple: The Development of Conservation and Indoor Climate in Nationalmuseum, Sweden

In: Carlo Manfredi (ed.), Addressing the Climate in Modern Age's Construction History: Between Architecture and Building Services Engineering (pp. 147-169).

Springer

https://doi.org/10.1007/978-3-030-04465-7

N.B. When citing this work, cite the original published chapter.

Published in DiVA with permission from Springer.

Permanent link to this version:

http://urn.kb.se/resolve?urn=urn:nbn:se:uu:diva-382734 
Carlo Manfredi

Editor

\section{Addressing the Climate in Modern Age's Construction History}

Between Architecture and Building Services Engineering 


\section{Not Just a Summer Temple: The Development of Conservation and Indoor Climate in Nationalmuseum, Sweden}

\section{Mattias Legnér}

Abstract This contribution examines the building and management of Nationalmuseum in Stockholm, and explores how conservation and indoor climate was shaped by technological development and how views on the running of a museum building shifted.

It is important that Nationalmuseum will become not just a summer temple, which strangers admire during their brief visits, but that it is a home to the fine arts, where we can be comfortable all year around, where we can stay and study even in the long and cold winters of Scandinavia (Sander 1866, 38).

\section{Introduction}

This essay examines the building and management of Nationalmuseum in Stockholm. Today the building has just recently been reopened after years of renovation and fitting of a new system that will control the indoor climate. This means deep interventions in a nineteenth-century building that was not designed to be airtight or to be heated all year around. The renovation gives a reason to ponder on how the building originally was designed and constructed, but also how it was managed over time. The climate of the house has been an issue ever since the building was constructed in the early years of the 1860 s (Fig. 1). It was fitted with a central heating system already then, but the building proved difficult to heat in winter and to ventilate in summer. There were continuous problems with dehydration of organic materials in the art collections in winter-time, and with too much sunlight exposing fragile art in the warmer season. Curiously, the introduction of artificial humidification first around

\section{Legnér (四)}

Department of Art History/Conservation, Uppsala University,

Campus Gotland, Visby, Sweden

e-mail: mattias.legner@konstvet.uu.se

C) Springer Nature Switzerland AG 2019 
1930 and then again in the 1950s did not solve the problem of dehydration. On the contrary climate problems became ever more complex around the mid-20th century because of the introduction of motor traffic with its exhausts, and increasing demands on a stable indoor climate in art museums. ${ }^{1}$

How did museums balance the needs of their collections, against the needs of staff and visitors? What considerations where made when choosing heating and ventilation for a museum at this time? In order to illuminate these questions, archival sources from Nationalmuseum, Riksarkivet (National State Archives) and the engineering and architectural company SWECO have been used. Överintendentsämbetet (Board of Public Works and Buildings, abbreviated ÖIÄ) was the custodian of government buildings, followed by Kungliga Byggnadsstyrelsen (Board of Building and Planning, abbreviated KBS) after an organizational shift in 1918. The museum was thus responsible for the management of its collections but not of its building. Until 1939 there was also a second museum housed in the bottom floor: Statens Historiska Museum, the National Historical Museum.

If the museum had a complaint on the performance of the building or the heating system, it would have to notify ÖIÄ (or KBS after 1918), which then would decide how to act. Judging by archive sources, it becomes evident that ÖIÄ had small means to make more demanding interventions in existing buildings, and often complaints seem to have been more or less ignored because of lack of resources. By studying the correspondence it is possible to gain a better understanding of how museum management perceived indoor climate and how ÖIÄ responded.

The purpose of the essay is to explore how the construction and management of the indoor climate was shaped by technological development and how views on the running of a museum building shifted. Nationalmuseum was fitted with a hot water central heating system. In the early 1860 s this was something hardly heard of in Sweden at this time. In general, the central heating systems used at that time were caloriphers, furnaces that heated the air that was then circulated through the building.

There were firms in Stockholm installing piping, but none of them was considered competent enough to do the installations in Nationalmuseum. Most entrepreneurs in Stockholm worked with gas piping, not with water or sewer piping. ${ }^{2}$ In the early 1860s it was still not evident that a public building should be equipped with this kind of heating, despite the relatively long and cold winters in Stockholm. Public buildings in general were heated with local fireplaces, most often tile stoves produced in the city.

Today it is well known that control of indoor climate is key to the management of collections. Too much heat makes the air dry, which may cause damage to fragile objects such as paintings on panels or wooden furniture with veneer. Too little heat makes the air very humid, which promotes mold, vermin, corrosion and rot. What is considered "too little" or "too much", however, has changed since the nineteenth

${ }^{1}$ Legnér \& Geiger (2015)

${ }^{2}$ Stålbom (2010). In 1861 Stockholm opened its first waterworks with $30 \mathrm{~km}$ of piping. century. ${ }^{3}$ The essay explores why central heating was installed in the museum, what the expectations on its functioning were, and how building and museum management (they were - and are- separate from each other) continuously commented on its performance in the decades following the opening of the museum, up until the 1970s when air pollution had become a serious problem demanding a technical solution.

\section{The Decision to Build a Museum}

Museums were not alien to Swedish culture of the mid-nineteenth century, but they were few and almost none had a building that had been designed to house a museum. The best museums were the ones belonging to the universities in Lund and Uppsala, where collections had been accumulated over a long time. Swedish architects and artists knew especially German, French and Italian museums. A common problem in Western and Northern Europe was how to use sunlight most efficiently in museums and libraries. European museums of the nineteenth century were generally dark, gloomy places which had very limited hours during winter time since they could not be heated efficiently and were completely dependent on natural lighting. Kunsthalle in Karlsruhe, for example, was open for two hours per day in wintertime, while museums in Berlin where open for four hours in the middle of the day. ${ }^{4}$

There had been voices calling for a new national museum building in Stockholm since the early nineteenth century, when parts of the royal collections were transferred from having been royal property to becoming state property. The collections were kept in a number of places inside and outside of Stockholm that were not easily accessible to the public, such as Gripsholm Castle, Riddarholmen Church and the Drottningholm and Ulriksdal Palaces. At least a couple of these places were clearly not suitable to house collections because of humidity and lack of heating. ${ }^{5}$

At the time (1845) when a decision was made to build Nationalmuseum, it was an astonishingly expensive project for state government. Around mid-century Sweden was still an agrarian economy of which the vast majority of the population lived outside towns and made their income on agriculture, forestry, fishing and some handicrafts. Using public funding to erect a monumental building in the capital that would celebrate Swedish arts and history was highly controversial. In the intellectual and political debates preceding the decision to build the museum the first seeds of modern Swedish cultural policies were planted. Per Widén has argued that there was in fact some support for an art museum in Stockholm in the 1830s, despite that the parliament had voted against a national museum as late as 1828 .

${ }^{3}$ Legnér (2015).

${ }^{4}$ Sheehan (2000).

${ }^{5}$ Legnér (2011). 
Critics were generally not hostile to the idea of a museum, but they were wary of the costs associated with its building. After the parliament's dismissal the king Karl XIV Johan went ahead with his own plans for an art museum next to his summer palace Rosendal on Djurgården in the outskirts of Stockholm. Djurgården was a large, forested area disposed by the king. ${ }^{6}$ Today it is a recreational area for Stockholmers and the home of a number of government institutions, among them a number of national museums, to mention a couple of its uses.

The issue of building a national museum divided the estates of the parliament: peasants and burghers opposed the project fervently, whereas nobility and clergy voted in favor of it. There was no doubt that this was a project that found most of its support in the king and the nobility. Some opponents claimed that the sum proposed was far from sufficient to design, construct and furnish such a building.

Nonetheless, since Riksdagen (the Swedish parliament) could not come to a decision it was instead decided by an extended committee of the museum project that 500,000 Riksdaler Riksmynt-a huge sum for anyone at the time--should be allocated to erect Nationalmuseum. ${ }^{7}$ It would become a huge investment for the Swedish state. Half a million Riksdaler Riksmynt would not suffice by far. In the end the construction would cost 4.5 times this sum. ${ }^{8}$ It was the most expensive building project since the erection of a new Royal Palace in the eighteenth century (the old one had been ravaged by fire in 1697).

\section{Building the Museum}

An initial object of concern was the location of the museum. There was lobbying for different locations. One party wished to see the museum erected very close to the Royal Palace and other government buildings on Helgeandsholmen. A military captain called Baltzar Cronstrand wrote several articles in the daily press, calling for a central location. The city of Stockholm wished to see the building erected on Kyrkholmen, which was a slum area not very developed but relatively close to the government quarters and the gentrifying northern part of the city. The location was furthermore facing the Royal Palace on the opposite side of the Norrström water. It furthermore facing the Royal Palace on the opposite side of the see why the city wished to see this area developed with a monumental public building. The costs for building there would be significantly lower than building on Helgeandsholmen, which was a densely developed area and poorly accessible site. With such a location it would have been very hard to keep the allocated budget. It seems as if the location on Kyrkholmen was chosen mainly because it was a poorly developed area close to the city center.

${ }^{6}$ Widén (2009)

${ }^{7}$ Malmborg (1941)

${ }^{8}$ Sander (1866).
Construction was begun surprisingly quickly, following a proposal made by the young and inexperienced architect Fredrik Wilhelm Scholander. It has been discussed why ÖIÄ went ahead with a proposal which evidently was incomplete. The board had not taken into account the size of the collections to be kept in the building. Corruption might have been one reason. ${ }^{9}$ This rash decision soon proved to be a mistake and construction of the foundation was interrupted after a year.

The design was heavily influenced by requirements not to exceed budget. When the location of Kyrkholmen had been decided by the King the superintendent of ÖIÄ and military officer Michael Gustaf Anckarsvärd, an architect who was the overseer of government buildings, proposed the dimensions of the building. It would have three floors and two courtyards illuminating the galleries. At this point the floor area allocated to different collections was decided after negotiation between the involved institutions. The art collections would occupy less than a third of the space, the royal library about half, the historical collections one seventh and the royal armory less than a tenth, which would make it very cramped. As the committee of the building project approved Anckarsvärd's promemoria, these basic dimensions (given in absolute numbers) became another object of concern.

The challenge of erecting a monumental building which could house six collections managed by three institutions, and keeping within the allocated budget, was immense. Never the less was this a highly prestigious mission for the superintendent's office which was in dire need of improving its reputation within public government. Military engineers who were closely connected with the royal court challenged from the outset the superintendent. Several military officers who had the King's ear, among them Baltzar Cronstrand and also Johan af Kleen, complained vigorously over Anckarsvärd's choice to let a young, just graduated architect draw the building. af Kleen had his reasons to complain, since he would be appointed as the new architect after the King had dismissed Scholander. The scholar Bo Grandien has argued that the disapproval of the proposal was directed not towards Scholander's person, but against his party-namely the Board of Public Works and Buildings (ÖIÄ). ${ }^{10}$

The king, influenced by critics in his entourage, now acted to marginalize the role of ÖIÄ. Suddenly, Scholander was asked to make a trip to Berlin in order to study museums. After a few days Anckarsvärd received new instructions from the king. Despite that Scholander remade his drawings to suit the king's wishes, he was soon sidestepped to the benefit of Johan af Kleen, who was the King's favorite Kleen would now be the one in charge during the trip to Berlin. Scholander's role was to accompany him in order to gather information for af Kleen. The object of the trip was now to consult the architect August Friedrich Stïler, who had been a pupil of the museum architect Leo van Klenze and who had recently designed the picture gallery Neues Museum. Shortly after the trip the trajectory of the project changed completely. Both af Kleen and Scholander were dismissed, and Stüler's position

${ }^{9}$ Grandien (1976)

${ }^{10}$ Grandien, "Det Scholanderska fiaskot". 
quickly shifted from having been an outside consultant to becoming the museum architect. Not only did the group of actors change but also the objects of concern. True, the foundation of the museum had already been laid, but Stüler was not instructed to keep within the specified budget. Suddenly, with an architect of international class present, there was no longer an obvious need to follow directives given by parliament. Riksdagen, which in $\mathbf{1 8 4 6}$ had taken the initiative to erect the building, had by the summer of 1847 become completely marginalized by the king's party. ${ }^{11}$ With Stïler the project could cleanse itself of an infected conflict between a fraction of military architects and ÖIÄ. Furthermore it received a competent and proven architect who was not easily criticized. By engaging a famous foreign architect the king hoped that the debate on the design of the museum could be put to an end and his wish be carried out.

Much like other museums of the nineteenth century Nationalmuseum was built at a time when museums were still viewed as mere galleries. Collections would be put on view, but in Sweden there was not the notion that museums also needed storage space, ample working space for staff and also workshops. The monumentality of the building - its potential of communicating national pride to the viewerwas considered to be of immense importance. August Stüler followed a tradition of German architecture when he argued that the building in itself should be a work of art with its character borrowed from "the dominant period of art history, such as "the fairest times of antiquity or the purest and most original period of Italian Renaissance."12 This would be a national museum, not just a museum of art. The intention was that all of the royal collections would be kept and displayed in the building. The plan was to bring a total of six collections together under one roof: The Royal Museum, The Royal Swedish Academy of Letters, History and Antiquities, The Royal Coin Cabinet, The Royal Clothing Chamber, the Royal book collection and the Royal Armory. ${ }^{13}$ In the end, the Royal book collection was never moved here but was installed in a new building of its own in 1874. Instead Nationalmuseum became a refuge for the royal art collections.

There had been complaints about the unsuitable environments of the Royal Palace and the Riddarholmen Church, which was the official burial site of the royal families. ${ }^{14}$ In the palace paintings had been subjected to dust and the flames and smoke from candles and torches, while moist air was pointed out as an environmental problem in the church. In 1866 they were in need of a skilled conservator The Riddarholmen Church was the home of many war trophies from the 17th century but was a very damp and cold environment, clearly not suitable for the display of armor, flags, drums and arms.

\footnotetext{
${ }^{11}$ von Malmborg, "Nationalmusei byggnad", 57.

${ }^{12}$ Laine (1976). Author's translation.

${ }^{13}$ von Dardel (1866).

${ }^{14}$ von Dardel (1866).
}

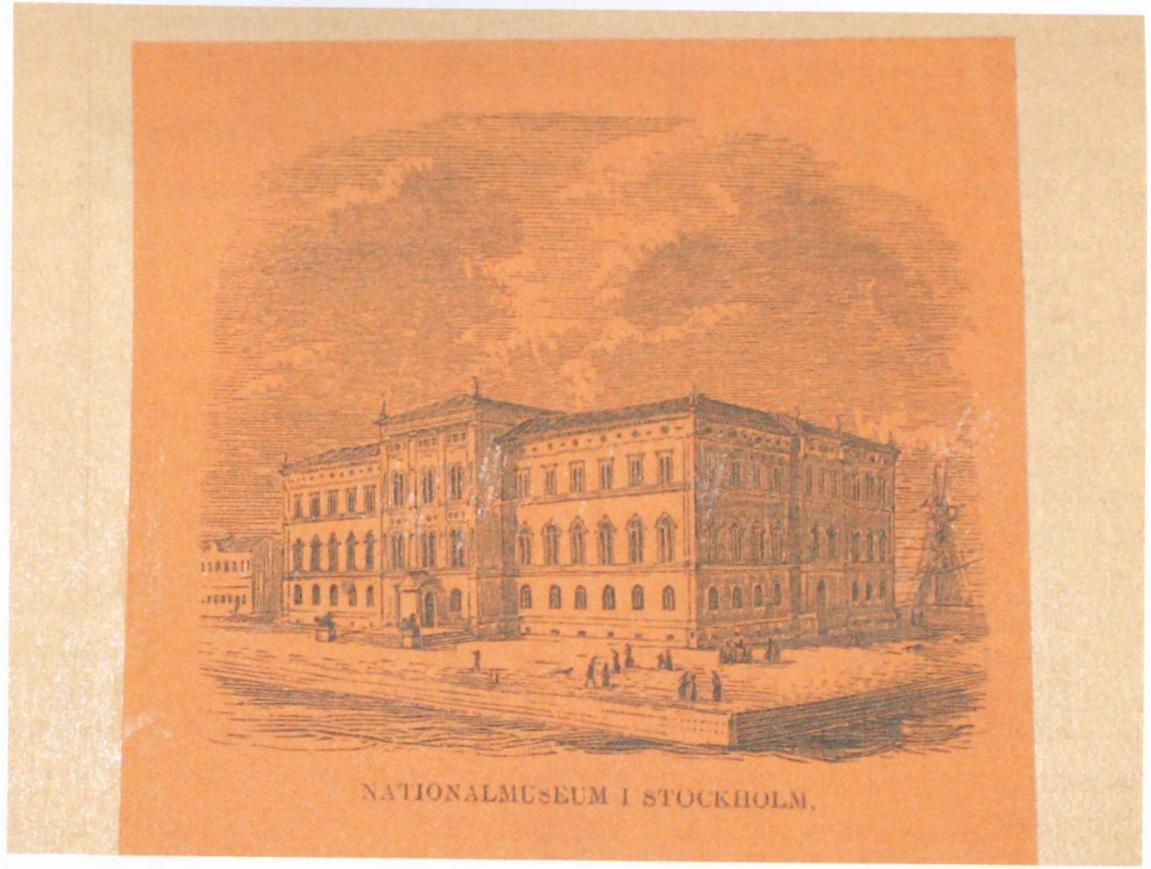

Fig. 1 The opening of Nationalmuseum in 1866 was big news in Sweden. Archival source Konstbiblioteket, Stockholm

\section{The Perkins System and Indoor Climate in Nationalmuseum in the Nineteenth Century}

We do not know much about the actual reasons for installing central heating in the building, but one reason seems to have been to protect national treasures. In the budget for the building of 1849 there was no cost included for a heating system, but ten years later funding for a central heating system had finally been approved by the parliament following a debate on what sort of system--hot air or hot water-should be selected.

In August 1859 the sum of 50,000 Riksdaler Riksmynt had been earmarked for heating devices. ${ }^{15}$ It is not entirely clear why Perkins ovens were selected in the end. What is clear is that the heating system was not viewed as part of the building construction, but as part of the furnishings. Funding for the interiors such as windows, floors, doors, and piping was not allocated until 1860, at which time the costs for building the museum seemed to have gone completely out of hand. One feature affecting the indoor climate that was not chosen because of budget

\footnotetext{
${ }^{15}$ von Dardel (1866)
} 


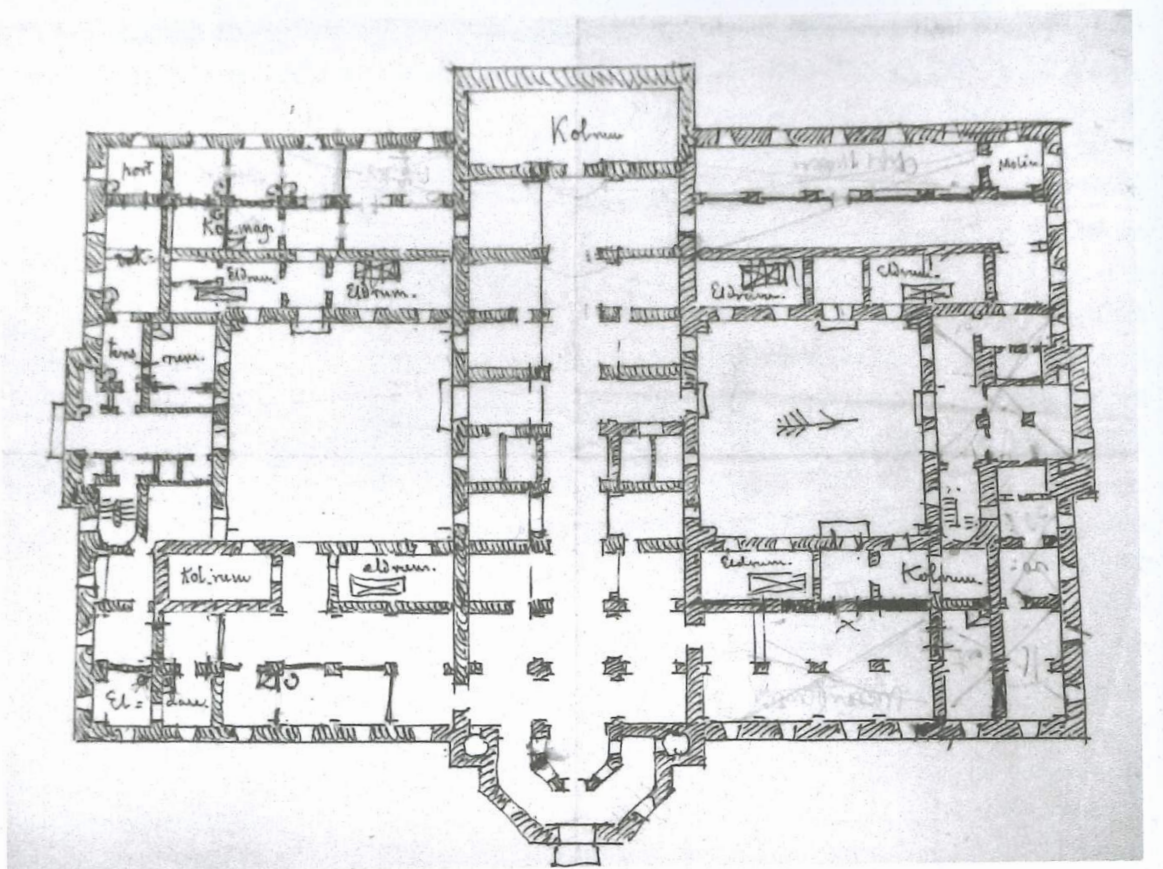
Fig. 2 Plan of basement in Nationalmuseum, 1860s. A large part of the basement was taken up by furnaces and storage for coal and firewood. There were six furnaces ("eldrum"), four rooms for
coal ("kolrum") and living quarters for the stoker and his family. Archival source Riksarkivet, Överintendentsämbetet, vol. DIrba: 3, plan S132

limitations was secondary glazing of windows. According to a calculation from 1859 this would have cost 30,000 Riksdaler Riksmynt, and was considered too expensive at this stage. 16

The costs were scrutinized by the state committee, which wrote a proposal for a budget to be decided by the parliament. The proposal was debated quite lively among the estates in September 1860. A number of members of the peasants' and burghers' estates were upset about the uncontrolled rise in costs. Now the building committee wanted the parliament to allocate additional funding for furnishing the interiors of the building. As part of this debate the burgers' estate discussed the choice of heating system, since this choice could have some effect on the budget. One member questioned the state committee and ÖIÄ's recommendation of a hot water system. He argued that a caloripher (hot air system) would be more affordable and also produce a healthier indoor climate. A caloripher would also dry out the moisture of the building quicker. Another member, Lars Hierta, partly conquered but asked if the sum of 60,000 Riksdaler Riksmynt was not set too high. Could not tile

${ }^{16}$ Riksarkivet (RA), Överintendentsämbetet (ÖIÄ), Flab: 55, "P.M." augusti 1859 (antagligen avskrift). stoves produce heat just as well and be much cheaper to install? However, as a conclusion of the debate the estate voted for approving the proposal of the state committee, which implies that there was not much critique against the budget. ${ }^{17}$

In order to understand the questions asked by the members of the burghers' estate, it is necessary to know that issues of heating had not yet acquired the exclusively technical character that they were given towards the end of the century. They could obviously become issues of political debate and were not discussed just by engineers or architects. Installing central heating in public buildings was not yet a common measure, and could be criticized for being a waste of public funds. ${ }^{18}$ Local fireplaces still dominated the heating of both private and public buildings.

In 1861 the construction work had progressed to the degree that the building committee was dissolved and replaced by a committee responsible for furnishing the interiors, including the fitting of a central heating system and tile stoves. This committee would mostly work with the issue of how to divide space in the building between the different collections and institutions involved. The committee consisted of representatives of these institutions: the superintendent of ÖIÄ Gustaf Söderberg, the curator J. Chr. Boklund, the custodian of antiquities (riksantikvarie) Bengt Emil Hildebrand and the librarian Gustaf Erik Klemming. The committee was led by the courtier and poet Gunnar Wennerberg. Since the committee could not reach consensus on how to divide the spaces, Wennerberg finally made a proposal of his own. His proposal meant that sculptures and trophies would be placed on the middle floor, antiquities on the ground floor and paintings on the top floor. As a consequence the book collection could not be housed in the museum but would instead need a building of its own. ${ }^{19}$

In 1862 the German firm of Johannes Haag in Augsburg at installed the Perkins system at a cost of 61,000 Riksdaler Riksmynt. The Perkins ovens meant that hot water would gravitate through a system of one-inch thick pipes. ${ }^{20}$ The pipes passed through a brick oven located in the basement. The network of pipes was fitted with an expansion loop. When the water expanded through heating it filled the loop, making it possible to heat the water beyond its boiling point. Water reached temperatures of $150-200{ }^{\circ} \mathrm{C}$. The advantage of this system was that it allowed much thinner pipes that could more easily be concealed than what low-pressure hot water heating needed at this time. The Perkins oven could achieve the same heating capacity as larger pipes of earlier hot water systems. ${ }^{21}$ A considerable drawback, however, was that the water was to be heated far beyond the boiling point in order

${ }^{17}$ Borgarstaindets riksdagsprotokoll $1859-60$, vol. 6, 363-375 (22 September, 1860); the statement of the state committee in Bihang till riksdagsprotokoll 1859-60, vol. 11, no. 180.

${ }^{18} \mathrm{~T}$ his was however about to change very soon. When the royal library, Kungliga Biblioteket, was planned a few years later central heating was seen as necessary at least in the public areas of the library.

${ }^{19}$ Bjurström (1992). See also Willers (1977). The royal library opened in 1874

${ }^{20}$ For an exhaustive description of the application and dissemination of Perkins systems see Manfredi (2013).

${ }^{21}$ Willmert (1993). 


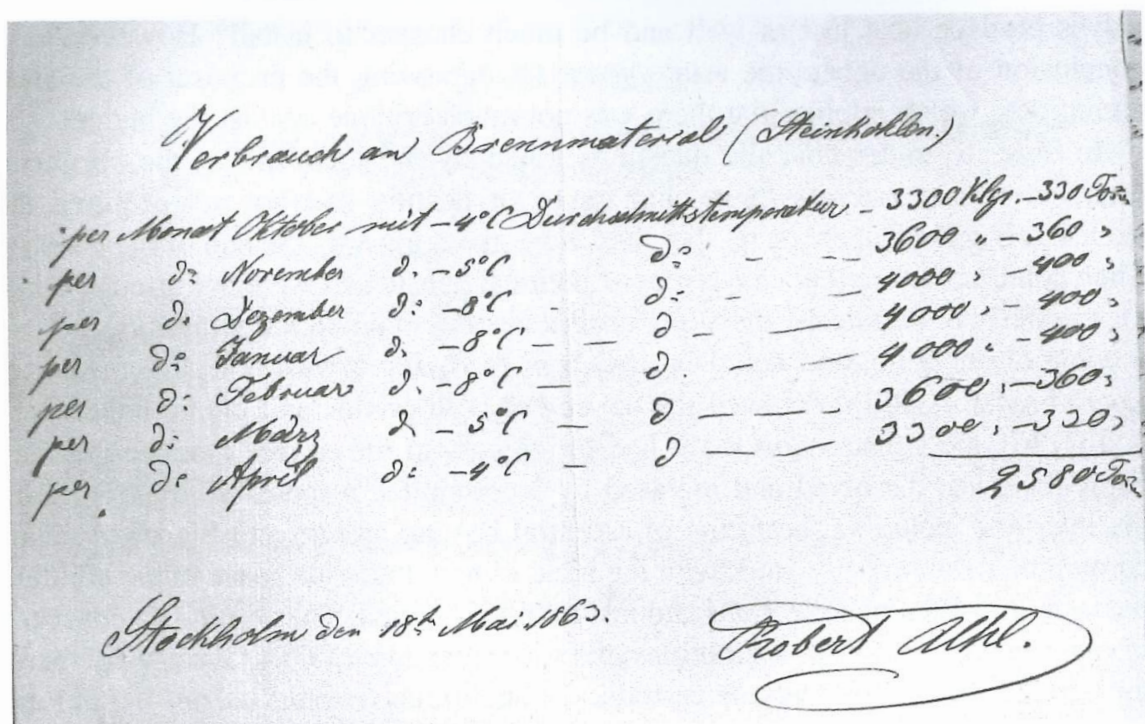

Fig. 3 One of the galleries in the beginning of the 20th century. There were heating pipes in the floor, covered by a protective grate (Sveriges Nationalmuseum $\mathrm{i}$ bilder, 1906)

to increase pressure, making it possible to raise pressure to dangerous levels where an explosion could occur.

Perkins ovens, first developed by the American born engineer Angier March Perkins mainly working in England, was installed in a number of public buildings in England in the 1830s. In 1835 the British Museum installed two of them, one for the reading room and another for the bird and print rooms. ${ }^{22}$ In 1833 a Perkins system was installed in the Court Room of Bank of England, and the Law Courts at Westminster is also supposed to have had a Perkins oven. ${ }^{23}$ Perkins systems have also been installed in many churches in England. ${ }^{24}$

In order to heat all the galleries in Nationalmuseum a total of six ovens were considered necessary by the entrepreneur. During operation (daytime only) they would be constantly fed and supervised by two stokers. In addition to that, a caretaker living in the building was contracted to operate the ovens and see to that they were not overheated. The caretaker was a mason who had been involved in putting the pipes of the Perkins ovens into walls and joists. ${ }^{25}$ Most of the basement was occupied with functions relating to the heating system: the ovens, fuel storage, and living quarters for the caretaker (Fig. 2).

${ }^{22}$ Ierley (1999)

${ }^{23}$ Hawkes (2012).

${ }^{24}$ See the CIBSE Heritage Group Website: http://www.hevac-heritage.org/victorian_engineers/ perkins/perkins.htm\#perkins2.

${ }^{25}$ RA, ÖIÄ, vol. Flab: 56, dnr 288, 5 April, 1866.
The museum was heated in daytime from September and well into May. There were repeated accidents with the oven: if the water was heated too much, pipes would burst and need to be replaced, and before spare parts had been obtained from Germany and put into place the ovens would not work. In the first years there was a supply of spare parts available in the museum, but this supply was not replenished and since there were many repairs it eventually became empty.

There were no radiators, but instead hot water was lead through seven kilometers of pipes embedded in the wooden floors. Heat from theses pipes rose through grates in the floor (Fig. 3). The hot water pipes were causing damages to the parquet, and the inside of the ducts had to be covered with plate to protect the floor. ${ }^{26}$

A representative of the Johannes Haag Company, an engineer named Robert Uhl, conducted the first tests of the system. The system was started in October 1862 and was used until the end of April 1863. This was considered to be a normal annual use of the system. In protocols from these tests there is information about fuel consumption and durchsnittstemperatur, i.e. average temperature. Exactly what is meant by average temperature here is not explained since there is no information on exactly where temperature was measured (Fig. 4). It is possible that average temperature was considered an overall average based on measurements on all floors. In the middle of winter 400 barrels of coal were used every month, and an average indoor temperature of $8{ }^{\circ} \mathrm{C}$ was reached. ${ }^{27}$

The system was vulnerable. During tests there were several explosions caused by too high pressure in the pipes. ${ }^{28}$ The weakest parts were the joints that could easily break if the pressure became very high. Water with a temperature of upwards $200^{\circ}$ $\mathrm{C}$ would then spray directly into a gallery or leak into the masonry walls. When there was leakage the system could overheat in just a few minutes, breaking the pipes inside the ovens. Later this risk of overheating would become part of the critique aimed at the Perkins system of Nationalmuseum.

The "heating apparatus" was evaluated and improved several times after the installation had been made. ${ }^{29}$ A first independent evaluation was conducted in 1863 by consultants employed by ÖIÄ. ${ }^{30}$ The average temperature was said to be $15^{\circ}$ above outdoor temperature at the beginning of the test. Temperature rose quickly during the test. At $25^{\circ} \mathrm{C}$ it was decided that the test should be cancelled because of the risk of damaging the wooden floor that had recently been put in. The test showed the powerful heat that the system could give off. It also shows that those involved were conscious of the influence of temperature on the humidity of air.

Consequently, this system was not perceived as optimal even at the time of its introduction. The fuel consumption was about $25 \%$ higher $(3.2$ barrels of coal

${ }^{26}$ Nationalmuseum (NM), protocols in museum matters, vol. A2: 4, protocol 8 April, 1869.

${ }^{27}$ RA, ÖIÄ, FIab: 55, R. Uhl's calculation 5 December, 1863. 400 barrels should have been equivalent to $60,000-68,0001$, depending on which kind of barrel was used.

${ }^{28}$ RA, ÖLÄ, Flab: 55, utan datering.

${ }^{29}$ RA, ÖIÄ, Flab: 55, R. Uhl 17 June, 1863, and K. Styffe 18 February, 1864.

${ }^{30}$ RA, ÖIÄ, Flab: 55, nr 1863-06-16. 


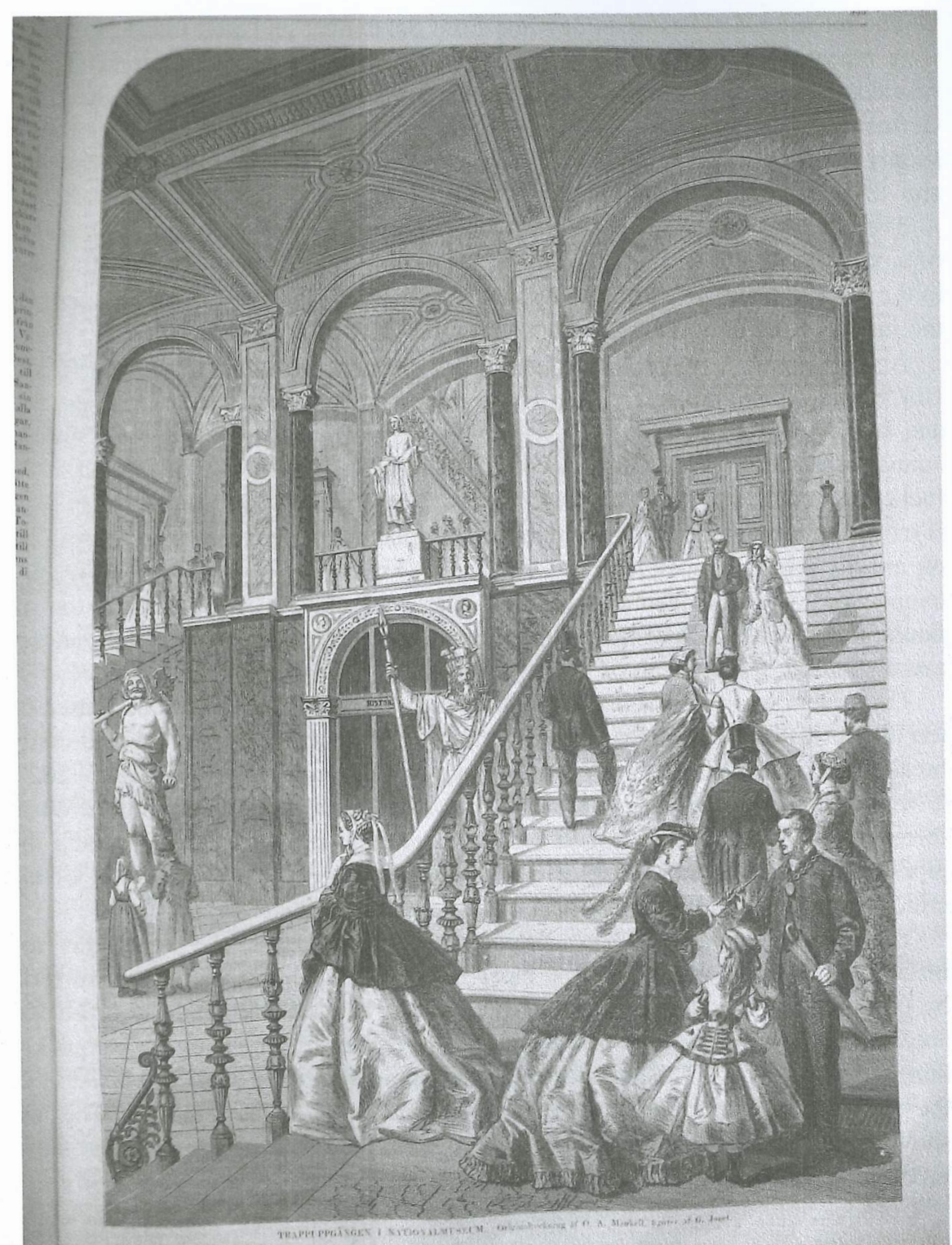

Fig. 4 Table of fuel consumption of the Perkin's system during the trials in 1862-63, showing the huge volume of coal used for heating the building in winter-time. Archival source Riksarkivet, Överintendentsämbetet, vol. Flab: 55

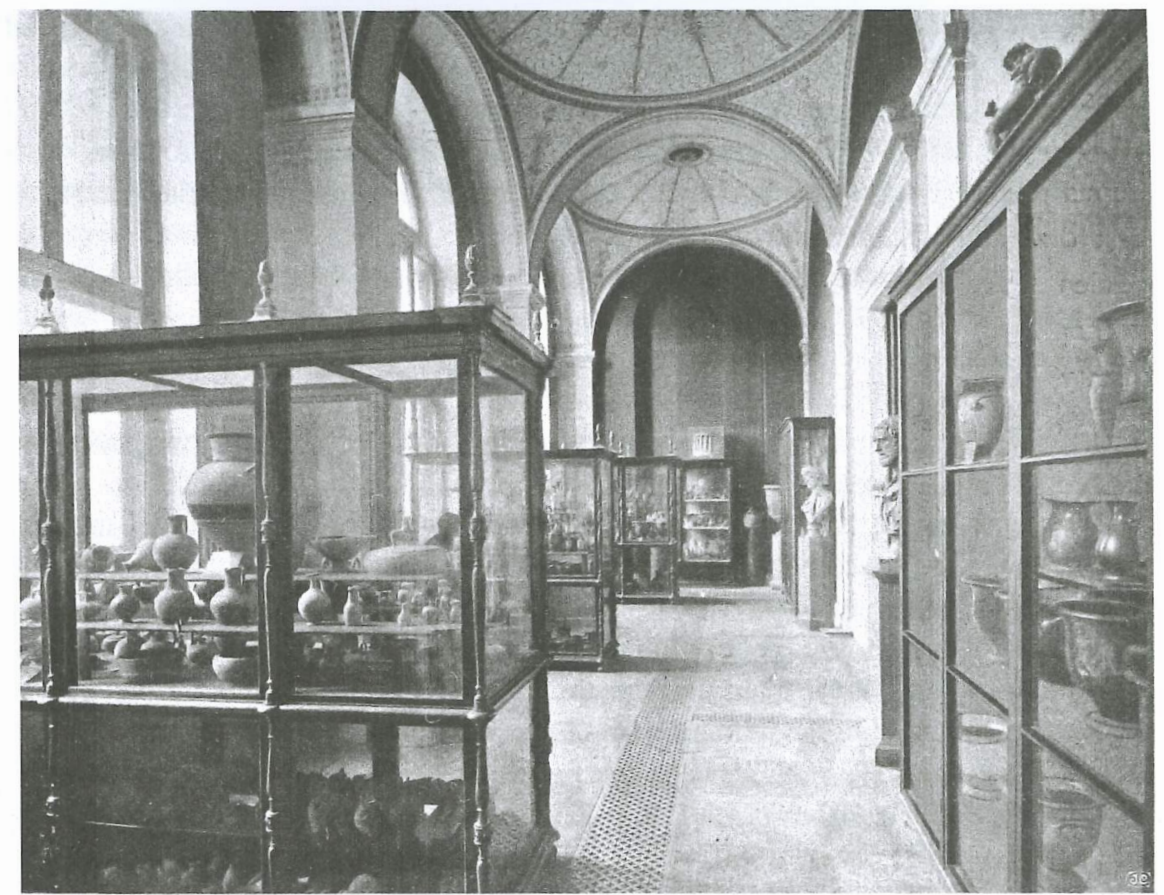

Fig. 5 The vestibule of Nationalmuseum. Image printed in Ny illustrerad tidning 1866, showing that visitors entered the exhibits fully dressed, only leaving canes and umbrellas at the entrance

instead of the specified 2.6) than predicted by the manufacturer, supposedly due to the large single pane windows through which a lot of heat was lost. ${ }^{31}$ In the first year of service the annual budget for fuel roughly equaled the salary for the three staff members maintaining the heating system and the costs for its repairs. ${ }^{32}$ About sixty years later, in 1923-24, the annual expenses for heating the building were 17,009 Kronor. A mix of birchwood, softwood, coal and cokes were used for fuel, with cokes as a dominating part. ${ }^{33}$

In 1865 it was decided to move 888 paintings from the Royal Palace, 67 from Drottningholm Palace, and 22 from Gripsholm Castle, which were royal castles with large repositories of paintings. ${ }^{34}$ The overarching purpose of this move was to give the collections a representative building, designed as a work of art itself, and make them available to the public for the first time. The move also had a symbolic meaning with the public government taking over the stewardship from the monarch. The collections that were moved to Nationalmuseum consisted only to a small

${ }^{31}$ RA, ÖIÄ, vol. FIab: 5, report by Styffe, Bolinder and Edlund, 8 February, 1864. ${ }^{32}$ von Dardel (1866).

${ }^{33} \mathrm{NM}$, protocols in museum matters, vol. A2: 59, form for fuel consumption.

${ }^{34}$ Sander (1876). 
extent of paintings: rune stones, sarcophagi, liturgical objects, archaeological findings of gold and silver, royal dresses, about 100 sculptures, arms and armor, porcelain, sketches and models, war trophies, 12,885 drawings and 60,000 engravings were also to be housed in the new premises. ${ }^{35}$ In 1884 trophies, arms and armors were moved to the Royal Palace in order to give room for the decorative arts.

The building housed Nationalmuseum, which managed the art collections, and the Royal Swedish Academy of Letters, History and Antiquities (subsequently called the Historical Museum) that kept historical and archaeological collections in the ground story and basement of the building. The art collections were kept on the upper two stories where lighting was better. Before 1930 the exhibition spaces had no electrical illumination.

Although source material commenting the indoor climate is scarce, there is evidence showing that objects brought into the museum quickly were damaged. The reason was that they had been stored in a humid and cool environment before they brought to a centrally heated building in which relative humidity should have been comparatively low. The Järstad triptych, which is a medieval wooden triptych, was placed in the custodian Hildebrand's office on the bottom floor (close to the ovens kept in the basement) of the museum, after which "the wood dried out, and the paint, applied to a gypsum primer, fell off in pieces and was badly damaged."36

A temperature of about $14{ }^{\circ} \mathrm{C}$ seems to have been the norm for the galleries in wintertime, but it was probably lower during the coldest part of the year. According to the first trials, the system should manage to raise the temperature $16{ }^{\circ} \mathrm{C}$ above outdoor temperature. The top floor with its skylights and insufficient heating sources should have been considerably colder, not to mention the attic where there was an outdoor climate. Early testing of the Perkins oven also showed that temperature varied between different parts of the building, depending on wind speed and direction. ${ }^{37}$ Keeping a steady temperature was not possible in any part of the building, neither in the 1860s, nor fifty years later. In 1916, for instance, the Director of Antiquities complained to the Superintendent about the chill in the offices heated by tile stoves only. Around this time the heating system was supplemented with a few electrical radiators, and a steam boiler was installed in the basement. ${ }^{38}$ Steam heat was used mainly to keep ice and snow off the skylights and not for thermal comfort. However, this circuit did not emit enough heat to keep the snow from building up. Skylights had to be shovelled and cleaned continuously in winter.

The Perkins system heated the galleries but did not serve the office spaces. In fact, the only reason why we know anything at all about temperatures in the building is that the staff complained about the level of thermal comfort. Tiled stoves

\footnotetext{
${ }^{35}$ von Dardel (1866).

${ }^{36}$ Quote from Nils Månsson Mandelgren in Stavenow (1972).

${ }^{37}$ RA, ÖIÄ, vol FIab: 55, report by Edlund and Folks, 29 December, 1864

${ }^{38}$ RA, ÖIÄ, vol FIab: 60, folder on steam heating, 9 September, 1915.
}

but also gas stoves were installed in the rooms of the curators and their staff, but in wintertime it could still get uncomfortably cold. The Director of Antiquities Hans Hildebrand complained about the cold in his office on the ground floor, which had a temperature of $10-12{ }^{\circ} \mathrm{C}$ in wintertime. ${ }^{39}$ In 1905 there were three studios there, but because of the chill the antiquarians could not work there. ${ }^{40}$

Storage spaces were not planned to fit into the building, but since the collections were too large for the building the attic and parts of the basements-premises were you would find the coolest, the most humid and the least stable climate-were taken into use for these purposes. In 1863 it had become apparent that some kind of storage space would be necessary in a near future, and for that reason a floor had been fitted in the attic. ${ }^{41}$ Some objects were moved down into the basement, which was a very damp place (the floors rotted away) due to the proximity of the lake Strömmen, located just next to the building and almost at the same level. ${ }^{42} \mathrm{~A}$ complaint from the fire department in 1915 about the fire hazard in the attic proves that it was still used for storing paintings and materials for restoration work. Also after the complaint in 1915 was the attic used for storage purposes.

The by far worst working conditions to be found in the building was the restorer's workshop (furnished in 1873) in the attic, where the temperature reportedly was between $0^{\circ}$ and $6^{\circ}$ in winter close to the stove. Already at this time it was seen as a fire hazard to have a stove burning continuously in winter in the attic where a fire could spread rapidly, and where few staff members moved about, but none the less the attic continued to be used as a restorer's workshop with an outdoor climate. In the 1890s the floor was filled with brick in order to make the attic more fire proof, a measure that should have made the attic even chillier.

Evidently there was a conflict between the wish to preserve the collections, and the demand for comfortable climate that was, if not comfortable, at least bearable in winter. Offices were heated with tile stoves that during cold winter days were fired constantly. Apparently this was not enough if one wanted to establish a climate appropriate for the working conditions.

In short, Nationalmuseum before the 1920s was a rather chilly place compared to later comfort standards. Visitors entered the exhibits fully dressed, only leaving canes or umbrellas to the porter (Fig. 5). It was heated only during working hours, allowing the building to cool off during the night. As a consequence, large amounts of water would condensate on the inside of skylights and windows in night-time. This water had to be led away to large tanks in order not to flood the galleries on the third story. One single winter night could produce as much as 1,000 litres of condensed water inside the building. ${ }^{43}$

${ }^{39}$ RA, ÖIÄ, vol FIab: 58, letter from Hildebrand, 8 December, 1902

${ }^{40}$ RA, ÖIÄ, vol FIab: 58, staff letter, 25 February, 1905.

${ }^{41}$ RA, ÖIÄ, vol Flab: 55, inspection report, 16 June, 1863.

${ }^{42}$ RA, ÖIÄ. On fire hazards: vol. Flab: 59, staff letter 16 August, 1915. On rot in the basement: vol FIab: 57, staff letter 26 June, 1889.

${ }^{43}$ RA, ÖIÄ, vol. Flab: 55, ref. 48, 16 February, 1864. 
The central heating system was primarily intended for the galleries, and this is why additional heat sources such as tile, gas and later also electrical stoves had to be used in other spaces. There was little possibility of controlling the indoor climate in the building, even though the Historical Museum obviously attempted to add moisture to the air by putting open water containers in the exhibitions, and there was also the risk of pipes bursting or a fire breaking out. ${ }^{44}$ In 1919 the Director of Antiquities Otto Janse complained to the Superintendent about excessive heating on the first story, where the collection of medieval polychrome wood was kept. $\mathrm{He}$ demanded that the pipes be insulated since attempts to decrease the water temperature in the pipes had not worked. The pipes in the floor of the gallery were insulated with asbestos paper, but apparently this did not decrease air temperature much. ${ }^{45}$ Instead the Historical Museum tried to humidify the air by putting out containers of water. When temperature was raised throughout the building after 1930 , the problem of dry air would become more serious.

\section{Demands for Electrification and a New Heating and Ventilation System}

An incident in 1923 made some of the problems with the existing heating device painfully apparent. The walls of the French gallery had recently been repainted, but soon it became clear that the hot water pipes dirtied the walls and the ceiling, making the newly renovated gallery look old and grimy again. Curator Axel Gauffin made an attempt to reduce the blackening effect by installing an oak bench on the walls, just above the conduits in the floor. ${ }^{46}$ This had little, if any, effect. Dirt just stuck to the wall harder and higher up, and after an accident where a visitor had stumbled on the bench and damaged a painting, the bench was removed. This, and surely also other circumstances, made Gauffin officially condemn the Perkins oven as being hopelessly outdated and unsuitable for a modern museum building:

the outdated heating device of the building, as unsound for the visitor and the staff as for the objects of art, and whose replacement with a new system will prove necessary in short, for the reason that with the existing system heating the museum in the evenings is impossible. Because of this, an obstacle for the progression of the museum into an educational institution for the people has been laid. ${ }^{47}$

\footnotetext{
${ }^{44}$ RA, Kungl. Byggnadsstyrelsen (KBS), Intendentsbyrån, vol. F1A: 116, letter from O. Janse, 18 February, 1919.

${ }^{45}$ RA, KBS, vol. F1A: 116, letter from O. Janse, 18 February, and letter from H. Theorell, 11 March, 1919

${ }^{46} \mathrm{NM}$, protocols in museum matters, vol. A2: 58, 3 May, 1923.

${ }^{47}$ Meddelanden från Nationalmuseum $n r$ 48, Nationalmuseum, Stockholm 1923, 4. Author's translation.
}

The argument, thus, was that the existing device was a risk both for collections and humans. If Nationalmuseum was to become an institution attractive and available to the public, it should also offer a comfortable environment.

The campaign for a new heating system that Gauffin had initiated in 1923 was continued in the following years. He argued that heat and soot from the pipes that were located almost directly beneath the paintings caused permanent damages to the objects of art. Because of this, he requested that the National Board of Building and Planning (which managed the building) would make a serious investigation of how a new system should be designed. ${ }^{48}$ In 1925 , a committee was appointed to investigate the needs of the museum, with Gauffin as one of the members.

There was also a need for electrification of the museum in order for opening hours to be extended into the evening, making artificial illumination necessary. Gauffin meant that the museum should be able to guarantee the preservation of both art on display, and the art deposited in storage spaces. Good storage facilities with adequate climate was thus necessary, since "these separated objects have the same right as the displayed ones to be preserved for the future - until the day when they perhaps are valued again - the verdict of what is valued and what is unimportant is cast anew by every generation." ${ }^{49}$ In these words, Gauffin summarized much of the ethos of modern conservation ideology. If nothing of the collections was to be sacrificed, adequate storage had to be organized for all the collections.

In the annual reports of 1926 and 1927, the Perkins ovens were described as a threat to both staff and collections. A fire inspection resulted in the discovery that wood in the floor had charred due to the heat from the pipes. There was obviously the risk of a fire breaking out, with disastrous consequences for the national treasures. If a pipe would blow and destroy an invaluable piece of art, the loss would be more expensive than a new heating system.

On the other hand, if the museum was heated and illuminated at night, it would have all the chances of becoming a popular institution with an important educational mission. Before 1930, the museum was available for working people only on Sunday afternoons. In the weekdays the museum closed before people left their work. There was a combination of arguments that together motivated the expensive removal of the old oven and the fitting of a modern heating and ventilation system. together with electricity.

\footnotetext{
${ }^{48} \mathrm{NM}$, protocols in museum matters, vol. A2: 59, 11 November, 1924.
}

${ }^{49}$ Meddelanden från Nationalmuseum nr 49, Nationalmuseum, Stockholm 1923, 20 


\section{Forced Air Ventilation and Humidity Control}

The National Board of Building and Planning gave the task of designing a heating and ventilation system to the ventilation engineer Hugo Theorell, who had long experience from working with buildings of historical value. Among other projects he had fitted central heating in the Royal Palace in 1912. Theorell would have to find a solution that would produce a climate that would be suitable for both collections and humans and that had an acceptable design. ${ }^{50}$

Theorell suggested a solution with hot water being distributed to radiators placed in niches in the galleries, but this was not accepted by the museum. Radiators were accepted in the offices and the small display rooms, but not in the galleries. Visible radiators would not have been aesthetically acceptable in any art gallery of the time. They were considered ugly and would decrease the surfaces available for displaying art. Nationalmuseum needed more space for displays, not less.

In 1929-31 the extensive work of installing heating, ventilation and electricity was carried out. The hallway and the galleries would be heated by air coming from three concealed heating chambers. Air was taken in from the entrance, filtered and heated but not humidified (Fig. 6). Gauffin had worried that panels and frames of wood would run the risk of being dehydrated, but Theorell did not think this was a serious risk. In his final report, Theorell did not mention the importance of RH levels, only considering that temperature was not supposed to vary abruptly.

He was of the opinion-which was common at the time - that temperature should be kept as low as possible where vulnerable objects were kept such as furniture or polychrome wooden objects. It was more risky to use radiating heat than to add already heated air to a room, he said. ${ }^{51}$ This argument was developed in an undated pro memoria written by Theorell after his work on Nationalmuseum. The PM has been found in the archive of his firm Hugo Theorells ingenjörsbyrå, which is today owned by SWECO and kept at its head office in Stockholm. In it he explores the problems of heating museums, and says that relative humidity and air exchange rate, not temperature, are the most important factors to consider. The importance of keeping a steady and "appropriate" level of RH between 45 and $60 \%$ in order to "counter damaging dehydration of the air" is underlined. ${ }^{52}$ This leads him to the conclusion that humidified air is the superior way of controlling the indoor climate of museums. He disqualifies the techniques that had been used at Nationalmuseum and other art museums in which staff had been putting bowls of water in the galleries or kept windows open in order to humidify the air. The PM also explains why the air inlets were situated close to the ceilings of galleries:

${ }^{50}$ SOU 1931: 8, Ny värmeledning samt elektrisk belysningsanläggning $i$ Nationalmuseibyggnaden i Stockholm, Kungl. Byggnadsstyrelsens Meddelanden 3, Stockholm 1931.

${ }^{51}$ Theorell in SOU 1931: 8, 22.

${ }^{52}$ SWECO archive, H. Theorells ingenjörsbyrå, "Uppvärmning och ventilation av museer”, 2.

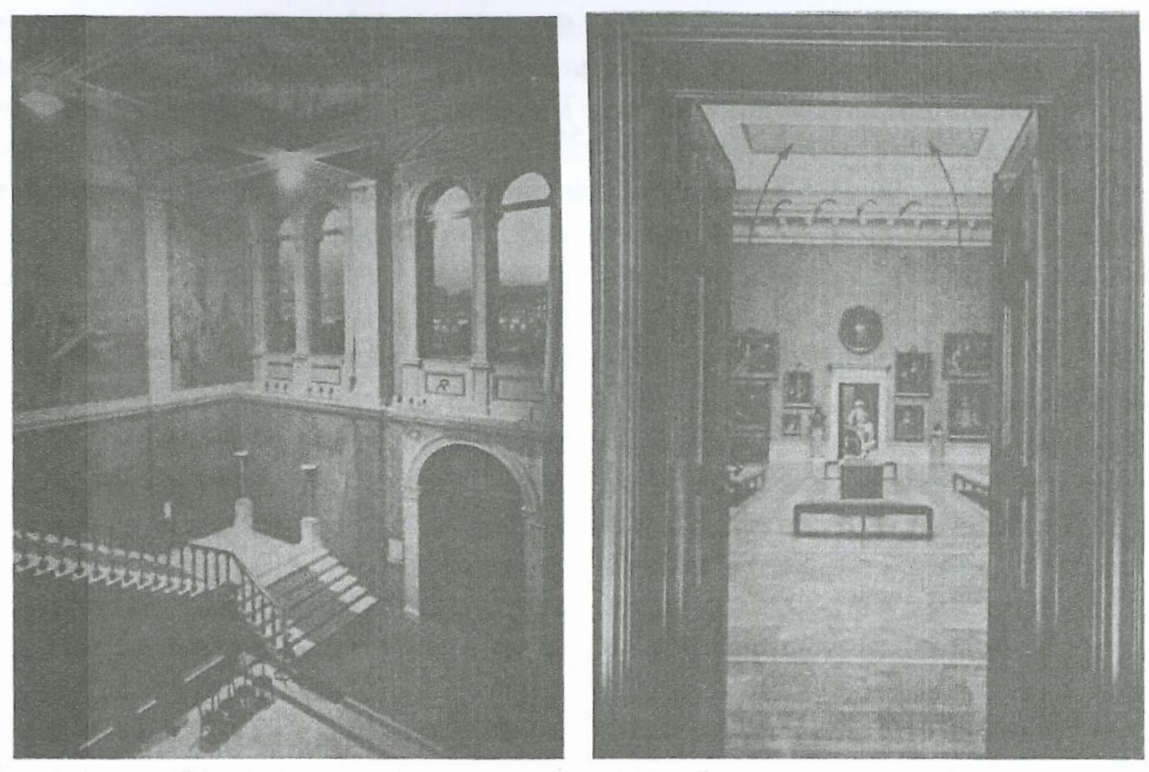

Fig. 6 The new heating and ventilation system installed in 1929-30 drew preheated air from the vestibule and upwards through the building. Inlets were placed in the cornices of the galleries and outlets were integrated in the skylights (Mouseion 1934)

. openings for air intake into a room are arranged so that objects are not directly exposed to the warm flow of air, and it is also preferrable that the movements of the layers of air and air movement around vulnerable objects are kept as small as possible, as the air movement itself boosts the negative consequences, which the character of the air can bring in general. $^{53}$

The PM confirms that Theorell, at least after having done the intervention in Nationalmuseum, was up to date with international research on the subject of indoor climate in museums. It also proves that he considered the control of RH as an important feature of indoor climate in museums.

The effects of a much drier indoor environment quickly became evident to the curator in 1931. Clearly, the last two requirements - human comfort and aesthetics -were considered the most important ones, whereas the climatic needs of the collections were down-played somewhat by the engineer. The indoor temperature was raised since visitors no longer were required to enter the galleries carrying their outer garments. Thus the level of human comfort was raised in several ways and not just by increasing the temperature.

The powerful intake of outdoor air made the environment very dry the first winter. Previously there had been just the natural ventilation of the building, which

${ }^{53}$ SWECO archive, H. Theorells ingenjörsbyrå, "Uppvärmning och ventilation av museer", 4. Author's translation. 
of course had been much less efficient than electrical fans. These were working during open hours. Gauffin's fears had proven to be real. Especially panels in the Dutch collection began to show cracks. The new ventilation system needed to be supplemented with humidifiers quickly. ${ }^{54}$ In this way, Nationalmuseum was the first museum in Sweden to obtain mechanically humidified air. Apparently, the fitting of humidifiers in 1932 seems to have satisfied the museum for the time being. Issues of humidity do not appear in sources again at Nationalmuseum until the 1950s, when additional humidification was required to meet new norms of indoor climate. Then new requests were made for raising and keeping the RH level steadier than before.

The Nationalmuseum system with heated and humidified air was observed at the 1932 annual meeting of the Scandinavian Association of Museums. ${ }^{55}$ In the 1930s with its unmatched period of museum building in Sweden, the issue of climate would be discussed more thoroughly for the first time. ${ }^{56}$ The 1932 meeting made it apparent that scientifically based knowledge on how climate affected collections in different ways still was very limited in Scandinavia. It was easy enough to make measurements of temperature and RH levels, but Sigurd Curman who had become Director of Antiquities, wished to know how climate actually affected the different materials of museum objects. ${ }^{57}$ Changes in the indoor climate needed to be monitored along with the reactions of collections. A more scientific approach to climate interaction with museum collections would not develop in Sweden until in the $1960 \mathrm{~s}$, but in the 1920s the recognition of climate induced problems was for the first time met by a museum in Sweden using humidity control.

\section{Humidity Challenging the Building and the Artworks}

Instead of lowering the temperature, additional humidity was added to the air from 1932 , but the air would still be too dry for much of the furniture, panel paintings and polychrome wooden objects. ${ }^{58}$ As a consequence more attention was paid to the relationship between temperature and $\mathrm{RH}$ inside the museum, and more humidifiers were installed. Evidence of the dry climate of the building was the return of the collections from their wartime storage space in 1945. They had been stored underground in a very stable climate. Upon their return to the museum, the much drier air had soon damaged furniture. This posed a problem for the museum in the way that objects needed expensive conservation.

${ }^{54} \mathrm{RA}$, KBS, Intendentsbyrån, vol F1A: 124, K. Bildmark's staff letter, 1 September, 1931.

${ }^{55}$ Skandinaviska museiförbundet. Berättelse över mötet i Lund och Malmö 31 maj-4 juni 1932, Nordisk Rotogravyr, Stockholm 1932.

${ }^{56}$ Legnér \& Geijer (2015).

${ }^{57}$ Curman (1933).

${ }^{58}$ Legnér $(2011,134)$
Adding humidifiers to the heating system did not prove to solve the problem of keeping a stable indoor climate, it was a technology that remained in use for the rest of the century. Windows in the galleries were single sash, which caused condensation on the inside of the glass panes. They were not added with secondary glazing for a very long time because of the costs involved. The building was managed by a government agency responsible for the care of state owned properties used for civilian purposes. The agency preferred having higher running costs for heating and ventilation rather than investing in costly improvements of the building. The introduction of moveable humidifiers in the early 1950 s was made possible by technological development and was based on the idea that the microclimate could be controlled in every gallery individually. Increased international cooperation put pressure on the museum to better control the indoor climate. This was however not possible to do in the smaller cabinets since these had outer walls with single sash windows. Compartmentalized control of humidity meant that exhibitions had to be organized according to groups of objects: for instance, canvas paintings could not be exhibited together with furniture or paper. ${ }^{59}$ This solution proves how pragmatically museum management looked at the issue of indoor climate. When foreign museums demanded a certain climate in order to put artworks on loan, the museum made some efforts to meet the stricter requirements. The in-house collection was instead subjected to seasonal variations in temperature and $\mathrm{RH}$. This management issue could be documented only by using the archive of the museum. Today it has (once again) become possible to display different kinds of objects in the same space.

In other countries it was becoming common to introduce HVAC in national art museums at this time. Increasing car traffic would bring the indoor climate of the museum to the fore in the 1960s. Research on air pollution showed that the building with its leaky windows and entrances functioned as a "chimney" drawing outside air with its particles of dust and tar into the building, making the pollution stick to walls and artworks. ${ }^{60}$ Museum management was profoundly sceptical to the idea of sealing the building and introducing full HVAC in order to clean incoming air. The museum was protected by national legislation and according to management it should not be retrofitted. Experience from the Louvre in Paris, which recently had been fitted with HVAC, proved that the system would only collect particles in the air. Sulphur and dioxide coming from industrial outlets and car traffic would not be stopped in this way. These were pollutants damaging paintings, paper and sculpture.

One unpredictable factor affecting indoor climate was visitor attendance. A Rembrandt exhibition in 1956 proved immensely popular as it attracted 290,000 visitors, but despite the humidity added by the bodies additional humidifiers were used in the exhibit space. ${ }^{61}$ The agency responsible for caring for the building

${ }^{59}$ Riksarkivet K (1953) Byggnadsstyrelsen, Intendentsbyrån, vol F1A: 127. H. Anderdahl's pro memoria "Förslag till befuktningsanordningar..." dated 19 Nov 1953.

${ }^{60}$ Bjurström (1976).

${ }^{61} \mathrm{RA}, \mathrm{KBS}$, Intendentsbyrån, vol. F1A: 127, O. Åkerstedt's pro memoria dated 22 September 1955. 
meant that the indoor climate should be possible to control without the addition of these extra humidifiers. Museum management was of another opinion and went against the advice of the agency. In an international study of 1960 the museum stated that it attempted to keep an indoor temperature of $18{ }^{\circ} \mathrm{C}$ and $\mathrm{RH}$ of 50 $60 \%{ }^{62}$ There is no possibility that the climate was actually kept within this very strict interval, since it was a 19th century building which was far from airtight and did not use an HVAC system. However, in order not to make international loans impossible it was important to state for the records that indoor climate should be kept as stable as possible.

An exhaustive report on the indoor climate problems of Nationalmuseum of 2004 showed that infiltration continued to be seen as a main problem for a very long time. Every hour half of the air volume of the building was exchanged. This uncontrolled inflow of air accounts both for the infiltration of pollutants and for making the air inside very dry in winter. In winter RH could fall well below $40 \%{ }^{63}$ In fact, infiltration of outdoor air has been a permanent feature of the building since the 19th century, and this problem has gained increasing attention since the 1950s as the outdoor air became more polluted. Climatization of parts of the building was made possible after the retrofitting and restoration work finished in 2018.

Previously the museum had wished to keep a very strict climate for blockbuster exhibitions on loan from foreign museums, while it had accepted that national collections were displayed in a much less controlled climate. The only way of proving that this actually happened at different occasions has been to visit the archives. It has also become clearer why so little was done for a long time to minimize infiltration of outdoor air. Sensitive objects were not moved to other premises where climate could easier be controlled except for conservation measures. Seen as a management issue, the conservation environment was influenced by a combination of factors of economy, human comfort, preventive conservation and design.

\section{References}

Bihang till riksdagsprotokoll (1859-60), vol 11

Borgarståndets riksdagsprotokoll (1859-60). vol 6, pp 363-375 (22 September, 1860)

Bjurström P (1976) Nationalmuseum och Blasieholmsleden. In: Hall T (ed) Nationalmuseum. Byggnaden och dess historia, Stockholm

Bjurström P (1992) Nationalmuseum 1792-1992, Stockholm, p 117

Climatology and conservation in museums (1960). ICOM, Paris

Curman S (1933) Museibyggnader. Byggmästaren. Arkitektupplagan 3(8):33-43

Grandien B (1976) Det Scholanderska fiaskot. In: Hall T (ed) Nationalmuseum. Byggnaden och dess historia. Nationalmuseum, Stockholm, p 66
Hawkes D (2012) Architecture and climate. An environmental history of British architecture 1600-2000. Routledge, London, pp 129, 131

Ierley M (1999) The comforts of home. The American House and the Evolution of Modern Convenience. Clarkson Potter, New York, p 127

Laine C (1976) Nationalmuseum och förebilderna. In: Hall T (ed) Nationalmuseum. Byggnaden och dess historia. Stockholm, p 85

Legnér M (2011) On the early history museum environment control: Nationalmuseum and Gripsholm Castle in Sweden, c. 1866-1932. Stud Conserv 56

Legnér M (2015) Conservation versus thermal comfort-conflicting interests? The issue of church heating, Sweden c. 1918-1975. Konsthistorisk Tidskrift 84(3):153-168

Legnér M, Geijer M (2015) Kulturarvet och komforten. Inomhusklimatet och förvaltningen av kulturhistoriska byggnader 1850-1985. Krilon, Klintehamn.

Malmborg B (1941) Nationalmusei byggnad. Ett bidrag till dess tillkomsthistoria. Nationalmusei årsbok, pp 36-37

Manfredi C (2013) La scoperta dell'aqua calda. Nascita e sviluppo dei sistemi di riscaldamento centrale 1777-1877. Politecnico, Milano, pp 52-80

Meddelanden från Nationalmuseum nr 48 (1923). Nationalmuseum, Stockholm

Meddelanden från Nationalmuseum nr 49 (1923), Nationalmuseum. Stockholm

Sander F (1866) Sveriges National-Museum, Stockholm

Sander F (1876) Nationalmuseum. Bidrag till taflegalleriets historia, vol 4. Samson \& Wallin, Stockholm, p 1

Sheehan JJ (2000) Museums in the German art world. From the end of the old regime to the rise of modernism. Oxford University Press, Oxford 116-119

Skandinaviska museiförbundet (1932). Berättelse över mötet i Lund och Malmö 31 maj-4 juni 1932, Nordisk Rotogravyr, Stockholm

SOU (1931): 8, Ny värmeledning samt elektrisk belysningsanläggning i Nationalmuseibyggnaden i Stockholm, Kungl. Byggnadsstyrelsens Meddelanden 3, Stockholm

Stålbom G (2010) Varmt och vädrat. VVS-teknik i äldre byggnader. Sveriges VVS MuseumSBUF-VVS Företagen, Stockholm, p 15

Stavenow Å (1972) Nils Månsson Mandelgren, Stockholm, p 122

von Dardel F (1866) Ett besök i Nationalmuseum. Tidskrift för byggnadskonst och ingeniörwetenskap, Stockholm, 2-9

Widén P (2009) Från kungligt galleri till nationellt museum. Aktörer, praktik och argument $i$ svensk konstmuseal diskurs ca 1814-1845. Gidlunds, Hedemora, pp 222-223

Willers U (ed) (1977) Hundra år i Humlegården, Stockholm, p 4

Willmert T (1993) Heating methods and their impact on Soane's work: lincoln's inn fields and dulwich picture gallery. J Soc Archit Hist 52:26-58

${ }^{62}$ Climatology and conservation in museums, ICOM, Paris 1960, 279.

${ }^{63} \mathrm{NM}, 2004$, AB 20 Teknisk förstudie (2004-10-01: 2). 